\title{
Central reassessment of GH concentrations measured at local treatment centers in children with impaired growth: consequences for patient management
}

\author{
Berthold P Hauffa ${ }^{1}$, Nils Lehmann ${ }^{2}$, Markus Bettendorf ${ }^{3}$, Otto Mehls ${ }^{3}$, Helmuth-Günther Dörr ${ }^{4}$, \\ Carl-Joachim Partsch $^{5}$, Hans P Schwarz ${ }^{6}$, Nikolaus Stahnke ${ }^{7}$, Heinz Steinkamp ${ }^{8}$, Elfriede Said ${ }^{8}$, Sabine Sander ${ }^{8}$ \\ and Michael B Ranke ${ }^{9}$ and participating members of the German KABI International Growth \\ Study/Internationale Genotropin-Langzeituntersuchung (KIGS/IGLU) Study Group \\ ${ }^{1}$ Department of Pediatric Hematology/Oncology and Endocrinology, University Children's Hospital, Essen, Germany, ${ }^{2}$ Institute for Medical Informatics, \\ Biometry and Epidemiology, University of Essen, Essen, Germany, ${ }^{3}$ University Children's Hospital, Heidelberg, Germany, ${ }^{4}$ University Hospital for \\ Children and Adolescents, Erlangen, Germany, ${ }^{5}$ Pediatric Endocrinology, University Children's Hospital, Kiel, Germany, ${ }^{6}$ University Children's Hospital, \\ München, Germany, ${ }^{7}$ University Children's Hospital, Hamburg, Germany, ${ }^{8}$ Pharmacia Corporation, Erlangen, Germany and ${ }^{9}$ Pediatric Endocrinology \\ Section, University Children's Hospital, Tuebingen, Germany
}

(Correspondence should be addressed to B P Hauffa, Klinik für pädiatrische Hämatologie/Onkologie und Endokrinologie, Zentrum für Kinderheilkunde und Jugendmedizin, Universitätsklinikum Essen, Hufelandstr. 55, D-45122 Essen, Germany; Email: berthold.hauffa@uni-essen.de)

\begin{abstract}
Objective: GH deficiency is diagnosed in children if serum GH fails to rise above a predefined cutoff value in response to at least two stimuli. Diagnostic decisions based on this testing are highly variable between centers and depend on the GH assays used. Considering the large spectrum of commercially available GH assays, we wanted to evaluate the agreement between assays, and to test whether assayrelated variability of diagnostic decisions could be reduced by reassessment of peak GH concentrations in a reference center.

Design: We reanalysed 699 peak GH serum samples obtained after GH testing of 382 children and adolescents from 19 centers using three reference assays and compared these results with those obtained with the local assays. A subgroup of 132 patients tested with the combination of insulin hypoglycemia test and arginine test was evaluated for changes in the assignment to the diagnostic group of GH deficiency.

Results: The mean difference between methods ranged from 5.4 to $10.3 \mathrm{mU} / \mathrm{l}$, slopes of the regression lines from 1.28 to 1.65 . Significant non-linearity was detected in five of six assay comparisons, indicating that most assay results cannot be interconverted by the use of a factor. Overall agreement between reference and local assays was only moderate. Significant changes in diagnostic assignment occurred when different assays were used on the same patient $(P<0.0001-P<0.0023)$. Based on GH remeasurement by one reference assay, 36 of 132 patients were categorized differently, with 35 patients changing into the GH-deficient group. Similar findings were obtained with the other reference assays.

Conclusions: To decrease variability in GH testing related to assays and cutoff values, we recommend nationwide reassessment of GH peak sera in reference centers. Decisions to treat GH deficiency should incorporate the reference center results.
\end{abstract}

European Journal of Endocrinology 150 291-297

\section{Introduction}

In most countries, the diagnosis of growth hormone (GH) deficiency in slowly growing children is based on the failure of serum $\mathrm{GH}$ concentrations to rise above a predefined cutoff value in response to at least two pharmacologic or physiologic stimuli (1). Considerable variability becomes apparent when patients diagnosed as GH deficient are retested $(2,3)$.

To the intrinsic variability of test results caused by physiological influences on the regulation of GH release $(4-6)$, variability is added by the testing instruments themselves. This includes the many different combinations of pharmacologic stimuli used for testing the somatotropic axis (7), and the multitude of commercially available assays for measuring GH. As a consequence, recognizing a child with GH deficiency depends largely on the $\mathrm{GH}$ assay used in a treatment center, and its validation for a specific setting of test procedures and cutoff values (8).

To further explore assay-related variability, we wanted to evaluate whether the results of $\mathrm{GH}$ testing in daily practise could be made comparable between centers. We tested the agreement between the $\mathrm{GH}$ 
peak concentrations measured in the participating centers with their local assays and the results obtained at repeat measurement in one reference center using three different $\mathrm{GH}$ assays. In addition, we asked how the diagnostic assignment would change when different assays were employed on sera from the same patient.

\section{Materials and methods}

\section{Samples and subjects}

Twenty-one German secondary and tertiary care centers diagnosing and treating children with growth disorders participated in the study. From 1 January 1998 to 31 December 1999 all consecutive children and adolescents who underwent functional testing of the somatotropic axis or evaluation of spontaneous $\mathrm{GH}$ secretion were considered for inclusion. GH concentrations were measured first using the local $\mathrm{GH}$ assay in each center. If serum was available from the samples containing the peak GH concentration, this was sent to a central laboratory (University Children's Hospital, Tuebingen) for re-evaluation. Seven hundred and ninety serum samples from 434 patients were reassayed centrally. Ninety-one of these results (52 patients, two centers) were excluded from the analysis. In 32 patients (61 samples), locally obtained $\mathrm{GH}$ results were not communicated. In nine patients (14 samples) the units used for reporting the $\mathrm{GH}$ data could not be verified. In seven patients (seven samples) the local assay was not reported, in three patients (six samples) the $\mathrm{GH}$ testing procedure remained unclear. In one patient who had undergone arginine testing twice, only one set of data was used. On using GH-releasing hormone stimulation, one patient showed low GH values when measured with the immunofunctional assay (IFA), in contrast to very high $\mathrm{GH}$ values obtained with all other assays, indicating the presence of a $\mathrm{GH}$ moiety with lesser bioactivity; this patient (two samples) was also omitted from the analysis. Thus, 699 peak GH serum samples of 382 children and adolescents (258 male, 124 female) from 19 centers were available for data analysis.

A subgroup of 132 patients with the most abundant test combination (insulin hypoglycemia test and arginine test) was evaluated for changes in the assignment to the diagnostic group of GH deficiency. Patients were diagnosed as $\mathrm{GH}$ deficient if the $\mathrm{GH}$ concentration remained below the assay-specific cutoff value in both tests. Otherwise, the patients were categorized as not $\mathrm{GH}$ deficient.

\section{Ethical approval}

The study protocol was reviewed and approved by the Ethics Committee for Medical Research of the University of Tuebingen. Patients were only submitted for functional testing of the somatotropic axis when results of the clinical examination or other laboratory tests indicated the presence of GH deficiency. Since some of the functional tests (e.g. insulin hypoglycemia) imply some risk, enough blood is routinely withdrawn for repeat laboratory measurements should anything go wrong in the laboratory. If the patient serum was not used up for that purpose, the remainder was sent to the reference laboratory for further measurements within our study. No additional blood was withdrawn for the study. Therefore the Institutional Review Board of the University of Tuebingen has not required us to obtain written informed consent from the parents for further analysis of the remaining serum.

Table 1 Characteristics and frequency of use of different human (h) GH immunoassay methods employed by the participating centers.

\begin{tabular}{|c|c|c|c|c|c|c|c|c|c|}
\hline $\begin{array}{l}\text { Assay } \\
\text { no. }\end{array}$ & Assay name & $\begin{array}{l}\text { No. of } \\
\text { centers }\end{array}$ & $\begin{array}{l}\text { No. of } \\
\text { patients }\end{array}$ & Tests* & $\begin{array}{l}\text { Assay } \\
\text { type }\end{array}$ & $\begin{array}{l}\text { Standard } \\
\text { calibrated } \\
\text { against: }\end{array}$ & Antibody (anti-hGH) & $\begin{array}{c}\text { Conversion } \\
\text { factor } \\
(\mathrm{ng} \times \mathrm{x}=\mu \mathrm{U}) \dagger\end{array}$ & Distributor \\
\hline 1 & HGH MAIAclone & 2 & 27 & 52 & IRMA & 1. IRP $66 / 217$ & 2 monoclonal (mouse) & 2.0 & $\begin{array}{l}\text { Serono/Biochem } \\
\text { (Freiburg, Germany) }\end{array}$ \\
\hline 2 & SERIA hGH & 3 & 97 & 184 & IRMA & 1. IS $80 / 505$ & 2 monoclonal (mouse) & 2.0 (1. IRP) & Serono/Biochem \\
\hline 3 & Nichols hGH & 5 & 55 & 115 & CLIA & 1. IS $80 / 505$ & $\begin{array}{l}1 \text { monoclonal (mouse), } \\
1 \text { polyclonal (goat) }\end{array}$ & 2.6 & $\begin{array}{l}\text { Nichols (Nichols Institute, } \\
\text { San Juan Capistrano, } \\
\text { CA, USA) }\end{array}$ \\
\hline 4 & $\begin{array}{l}\text { DPC Immulite } \\
\text { hGH }\end{array}$ & 4 & 28 & 45 & RIA & 1. IS $80 / 505$ & $\begin{array}{c}1 \text { monoclonal (mouse), } \\
1 \text { polyclonal (rabbit) }\end{array}$ & 2.6 & $\begin{array}{l}\text { DPC (Los Angeles, CA, } \\
\text { USA) }\end{array}$ \\
\hline 5 & Varelisa & 3 & 42 & 115 & EIA & 1. IS $80 / 505$ & $\begin{array}{l}1 \text { monoclonal (mouse), } \\
1 \text { second antibody }\end{array}$ & 2.0 & Elias (Freiburg, Germany) \\
\hline 6 & hGH-EASIA & 1 & 52 & 66 & EIA & 1. IS $80 / 505$ & $\begin{array}{l}2 \text { different mixes of } \\
\text { monoclonal } \\
\text { antibodies }\end{array}$ & 2.0 & $\begin{array}{l}\text { Medgenix (Nivelles, } \\
\text { Belgium) }\end{array}$ \\
\hline 7 & hGH-RIA & 1 & 81 & 122 & RIA & 1. IS $88 / 624$ & $\begin{array}{l}1 \text { polyclonal (rabbit) } \\
\text { against } 22 \mathrm{kDa} \mathrm{GH}\end{array}$ & 3.0 & $\begin{array}{l}\text { In-house assay } \\
\text { (Tuebingen, Germany) }\end{array}$ \\
\hline
\end{tabular}

IRMA, immunoradiometric assay; CLIA, chemoluminescence immunoassay; EIA, enzyme immuoassay; RIA, radioimmunoassay; 1. IRP, first international reference preparation; 1 . IS, first international standard.

*Response to pharmacologic stimuli or assessment of spontaneous secretion. †As supplied by the manufacturer. 


\section{Analytical methods}

The GH assays used in the participating centers (local assays) and their characteristics are detailed in Table 1. Samples containing the peak GH concentration were stored frozen for various lengths of time not exceeding 6 months at $-20^{\circ} \mathrm{C}$ in $300 \mu \mathrm{l}$ aliquots and sent to the central laboratory at the University Children's Hospital, Tuebingen (M B R), where $\mathrm{GH}$ concentration was reassessed in duplicate using three different reference assays. GH in serum measured with the reference assays was reported to be stable under these conditions over a time-period of up to 1 year.

The first reference assay (Tuebingen in-house assay) was an RIA calibrated against the First International Standard for somatropin (88/624). Its first polyclonal antibody is directed exclusively against $22 \mathrm{kDa}$ recombinant hGH. Analytical sensitivity was $0.15 \mathrm{mU} / \mathrm{l}$. The intra-assay (interassay) coefficients of variation (CV) were $\leq 7.9 \%$ at $\mathrm{GH}$ concentrations ranging from 3.6 to $56.4(8.7-30.6) \mathrm{mU} / \mathrm{l}$. The cutoff concentration established in Tuebingen was applied for rating the peak $\mathrm{GH}$ response as normal ( $\geq 24 \mathrm{mU} / \mathrm{l}$ ) or insufficient $(<24 \mathrm{mU} / \mathrm{l})$.

The second reference assay (AutoDELFIA hGH; Wallac Oy, Turku, Finland) was an enzyme-linked immunosorbent assay (ELISA) calibrated against the First International Standard for hGH (80/505) with two monoclonal mouse antibodies directed against different epitopes of $22 \mathrm{kDa}$ hGH. Analytical sensitivity was $0.03 \mathrm{mU} / \mathrm{l}$. Cross-reactivity with other proteohormones was $<0.1 \%$. The intra-assay (interassay) $\mathrm{CV}$ values at $\mathrm{GH}$ concentrations from 0.52 to $89.2 \mathrm{mU} / \mathrm{l}$ were $\leq 6.3 \%(\leq 5.0 \%)$. The cutoff value distinguishing between a normal $\mathrm{GH}$ reserve and $\mathrm{GH}$ deficiency was set at $26 \mathrm{mU} / \mathrm{l}$. In 20 patients (26 samples), there was not enough serum for parallel determinations with this assay.

The third assay used for reference (Active Immunofunctional hGH ELISA; Diagnostic Systems Laboratories, Webster, TX, USA) was an IFA calibrated against the First International Standard for somatropin (88/624). A first monoclonal mouse antibody is directed against a bioactive epitope of $22 \mathrm{kDa} \mathrm{hGH}$. Recombinant hGH-binding protein (GHBP) is the second binding agent. Analytical sensitivity was $0.18 \mathrm{mU} / \mathrm{l}$. Cross-reactivity with $20 \mathrm{kDa}$ pituitary hGH was $53.3 \%$. The intra-assay (interassay) $\mathrm{CV}$ values at $\mathrm{GH}$ concentrations from 1.47 to $38.13(1.44-45.8)$ $\mathrm{mU} / \mathrm{l}$ were $\leq 5.1 \%(\leq 9.6 \%)$. According to the manufacturer, the cutoff value distinguishing between a normal GH reserve and GH deficiency was set at $15 \mathrm{mU} / \mathrm{l}$. In nine patients (nine samples), there was not enough serum for parallel determinations with this assay.

The central laboratory (M B R) was blinded to the origin of the samples, the type of assay used and the GH values obtained at the respective centers, and the cutoff levels employed for the diagnosis of $\mathrm{GH}$ deficiency at these centers. The evaluating center (B $\mathrm{P} \mathrm{H}$ ) was blinded to the name of the referring center. Results are expressed as mU/l. Data given in $\mathrm{ng} / \mathrm{ml}$ were recalculated as $\mathrm{mU} / \mathrm{l}$ using the conversion factors given by the assay manufacturers (Table 1).

\section{Statistical methods}

GH results obtained at the different centers were combined and compared pairwise with the results of the central laboratory by the Bland-Altman plot (9) and the Passing-Bablok regression (10), using MedCalc software Mariakerke, Belgium (11)). These methods are non-parametric and do not require one assay to be assigned the role of an analytical gold standard. Subjecting the $\mathrm{GH}$ data to a common Box-Cox power transformation with $\mathrm{y}=\left(\mathrm{x}^{0.4}-1\right) / 0.4$ yielded a normal distribution. From the transformed data, the concordance correlation coefficient (12) was calculated as a measure of agreement between assays. Values for overall concordance $\left(\rho_{c}\right)$ between 0.2 and 0.7 indicate minor concordance, values between 0.7 and 0.85 indicate moderate concordance, and values larger than 0.85 indicate clear to high concordance. Whether the local assays and each of the three assays used by the central laboratory agreed in the assignment of a patient to a diagnostic group ( $\mathrm{GH}$ deficient vs not $\mathrm{GH}$ deficient) was assessed using the McNemar test and the $\kappa$ statistic (13). A $\kappa$ value between 0.4 and 0.6 indicates moderate agreement, $\kappa$ between 0.6 and 0.8 indicates clear agreement, and $\kappa$ between 0.8 and 1.0 indicates high agreement. The latter analyses were performed using SAS software version 8.2 (14).

\section{Results}

First, assay comparability with regard to peak GH concentrations was assessed using the Bland-Altman plot and the Passing-Bablok regression. Results obtained with the Bland-Altman method are displayed as scatterplots in Fig. 1. When the local assay results were compared with the three reference assays, the scatterplots displayed a widening range of differences with increasing GH concentrations, indicating that the variation of at least one method of each pair depended strongly on the GH concentration present in the sample. Also, because the mean of the assay differences was not zero, a bias between methods was demonstrated. This increased from the Tuebingen assay $(-5.4 \mathrm{mU} / \mathrm{l})$ to the DELFIA assay $(-6.0 \mathrm{mU} / \mathrm{l})$ to the IFA, which showed the greatest difference, measuring on average $10.3 \mathrm{mU} / \mathrm{l}$ lower than the local assays. The \pm 1.96 S.D. range of the assay differences was large when the local assays were compared with the reference assays: DELFIA, $\pm 51.1 \mathrm{mU} / \mathrm{l}$; Tuebingen assay, $\pm 52.2 \mathrm{mU} / \mathrm{l}$; IFA, $\pm 54.5 \mathrm{mU} / \mathrm{l}$. As the $\mathrm{GH}$ 


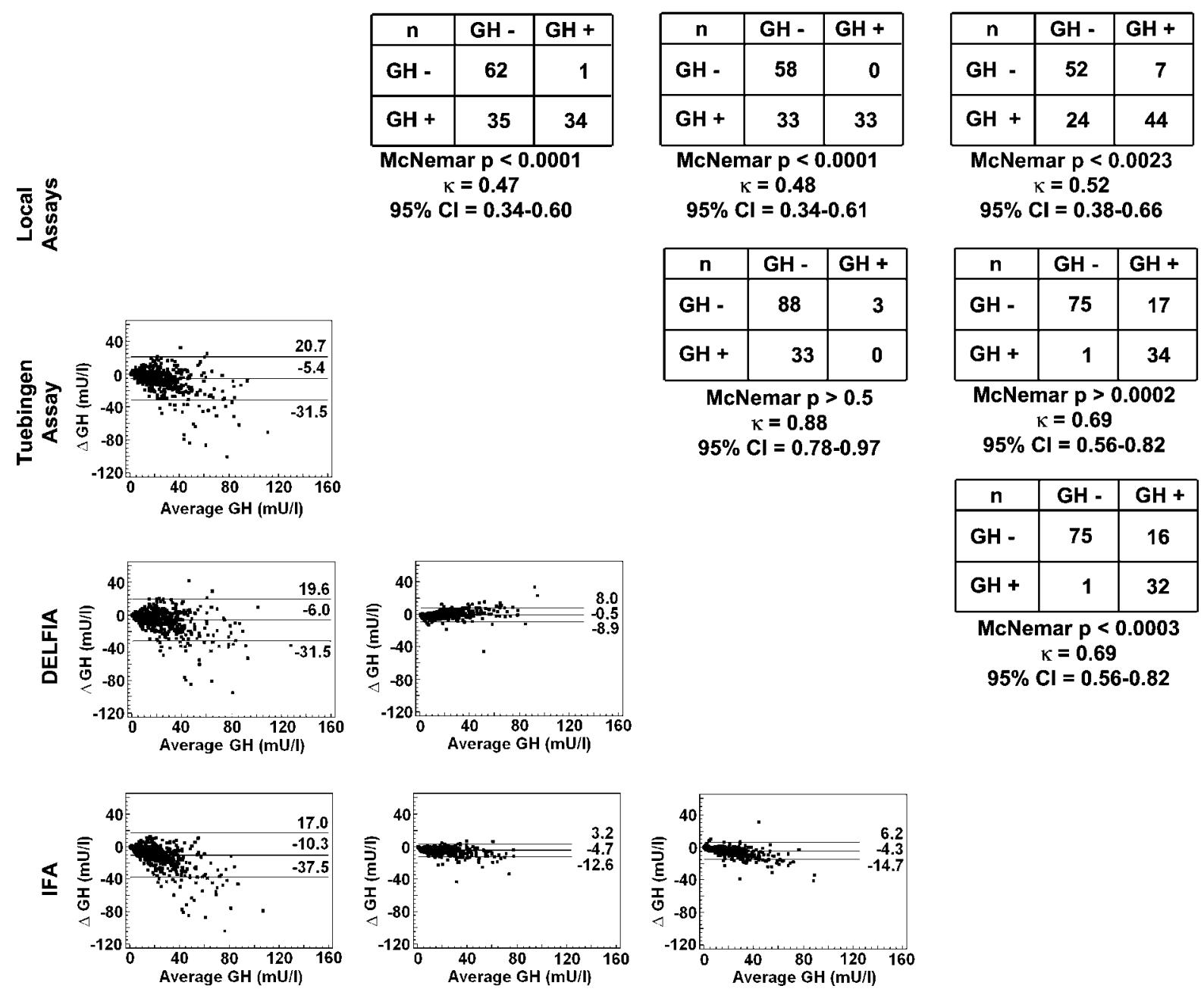

Figure 1 Pairwise comparisons of methods (local assays = all GH measurements obtained in the local centers grouped together). The scatterplots show Bland-Altman plots ( $x$ axis: average of GH concentrations measured with each method in mU/l; $y$ axis: difference of the same GH concentrations in $\mathrm{mU} / \mathrm{l}$. Horizontal lines and numbers indicate the mean and \pm 1.96 S.D. range of all differences). The graphs show comparison of diagnostic assignment of patients to the categories of $\mathrm{GH}$ deficient $(\mathrm{GH}-)$ and not $\mathrm{GH}$ deficient $(\mathrm{GH}+)$ using different assays (McNemar statistic indicating imbalance of diagnostic assignment; $\kappa$ coefficient with $95 \%$ confidence interval $(\mathrm{Cl})$ indicating concordance of assignment); $\mathrm{n}=$ number of patients (numbers in each cell indicate patients with concordant or discordant diagnostic classification).

cutoff concentrations distinguishing between $\mathrm{GH}$ deficiency and normal GH secretion were reported to be in the range of $20-26 \mathrm{mU} / \mathrm{l}$ at most centers, the implication is that apparently normal GH concentrations measured with the local assays can lie in the GH-deficient range when measured with the reference assays, and vice versa. In addition, a proportional error component was detected in the scatterplots, visible below the mean -1.96 s.D. lines as proportionally larger negative differences. This component is due to higher readings of the local assays in the high $\mathrm{GH}$ concentration range. Therefore, $\mathrm{GH}$ measurements obtained with these assays cannot readily be interconverted by the use of some factor after correction for the bias.

A different picture emerged when the reference assays were compared with each other. The best agreement was found between the Tuebingen assay and the DELFIA, with a bias of only $-0.5 \mathrm{mU} / \mathrm{l}$ and a \pm 1.96 S.D. range of $\pm 16.9 \mathrm{mU} / \mathrm{l}$. Comparison between the Tuebingen assay (DELFIA) and IFA revealed a slightly higher bias of $-4.7 \mathrm{mU} / \mathrm{l}(-4.3 \mathrm{mU} / \mathrm{l})$ and a similar \pm 1.96 S.D. range of $\pm 15.8 \mathrm{mU} / \mathrm{l}( \pm 20.9 \mathrm{mU} / \mathrm{l})$.

Additional information was gained by the PassingBablok analysis. Again, the least disagreement was found between the Tuebingen assay and the DELFIA. 
Table 2 Regression equations and $95 \% \mathrm{Cl}$ values of intercept and slope of the pairwise method comparisons calculated with the Passing-Bablok method (10).

\begin{tabular}{llrrrr}
\hline $\mathbf{y}$ & $\mathbf{x}$ & Regression equation & 95\% Cl intercept & 95\% Cl slope & Deviation from linearity \\
\hline Local assays & Tuebingen assay & $\mathrm{y}=-3.139+1.449 \mathrm{x}$ & -4.074 to -2.494 & 1.386 to 1.512 \\
Local assays & DELFIA & $\mathrm{y}=0.299+1.281 \mathrm{x}$ & 0.112 to 0.662 & 1.211 to 1.349 & $P<0.01$ \\
Local assays & IFA & $\mathrm{y}=0.797+1.651 \mathrm{x}$ & 0.284 to 1.149 & 1.58 to 1.721 & $P<0.01$ \\
Tuebingen assays & DELFIA & $\mathrm{y}=2.312+0.878 \mathrm{x}$ & 2.107 to 2.513 & 0.862 to 0.894 & $P<0.01$ \\
Tuebingen assays & IFA & $\mathrm{y}=2.775+1.125 \mathrm{x}$ & 2.513 to 2.969 & 1.103 to 1.146 \\
DELFIA & IFA & $\mathrm{y}=0.478+1.307 \mathrm{x}$ & 0.3 to 0.614 & 1.285 to 1.333 & $P<0.01$ \\
\hline
\end{tabular}

NS $=$ not significant. Significant deviations from linearity are indicated.

Regression equations with 95\% CI values for the intercept and the slope are shown in Table 2. The data were also tested for deviations from a simple linear relationship. A significant non-linearity was found with all comparisons except the TuebingenDELFIA pair. This shows that a conversion of the GH concentrations between assays based on a linear equation is not valid in these cases.

The strength of the agreement between assay results was quantified using the concordance correlation. With this method, overall concordance was highest between DELFIA and the Tuebingen and IFA assays $\left(\rho_{\mathrm{c}}>0.86\right)$. The concordance was lower between the local assays and the three reference assays $\left(\rho_{c} \leq 0.80\right)$ and lowest for the local assays-IFA pair $\left(\rho_{c}=0.71\right)$.

There were consequences for these differences in GH measurement in the assignment of the patients to the diagnosis of GH deficiency. A subgroup of 132 patients, in whom the diagnosis was based on a combination of an insulin hypoglycemia test and an arginine test, was investigated further. GH deficiency was assumed if the stimulated GH concentration was below the specified cutoff value in both tests. The diagnostic matrices for the pairwise assay comparisons are shown in Fig. 1 (graphs). A significant imbalance in diagnostic assignment occurred when different assays were used on the same patient $(P<0.0001-0.0023)$ : the only exception was the Tuebingen-DELFIA comparison. While the Tuebingen and DELFIA assays showed excellent agreement $(\kappa=0.88)$, only moderate agreement was found when local assays and reference assays were compared.

\section{Discussion}

Our data show that agreement between the results of GH assays used in 19 German tertiary and secondary centers experienced in the treatment of children with growth disorders is extremely variable. As a consequence, the probability that a short child will be diagnosed as GH deficient depends to a great extent on the $\mathrm{GH}$ assay and the cutoff $\mathrm{GH}$ concentrations used at the local center. These vary considerably between centers. We have also demonstrated that sending peak GH serum samples to a central laboratory for repeat $\mathrm{GH}$ measurement and using the remeasured data to adjust treatment decisions is a feasible way to reduce variability in the treatment decisions of childhood GH deficiency based on pharmacological testing in the setting of a nationwide health system.

More than 200 papers have addressed the subject of the variability of tests of $\mathrm{GH}$ release in children. This work has been extensively reviewed, and consensus guidelines have been formulated for the diagnosis of $\mathrm{GH}$ deficiency $(1,15)$ with the aim of decreasing this variability. There is still a gap, however, between these guidelines and the daily practise in European countries (16).

One major source of variability is the GH assay itself, as shown by the outcome of multilaboratory external quality-control assessment programs (17, 18). First, results depended on the assay standards. Three different International Reference Preparations or standards were used by the local and reference assays of this study. Two of them (IRP 66/217 and IS 80/505) are pituitary standards, originally defined in units (U) by bioassay, and 1 (IS 88/624) is a recombinant standard defined in mass units (mg) by amino acid analysis (19). Therefore, assay results based on the first two standards should be expressed in units. However, three of the seven study assays calibrated against pituitary standards expressed their results in $\mathrm{ng} / \mathrm{ml}$. These three assays all used the standard IS 80/505. To reconvert $\mathrm{GH}$ results to $\mathrm{mU} / \mathrm{l}$, one manufacturer recommended a factor of 2.0, whereas two manufacturers recommended a factor of 2.6. Thus, variability arose not only from the use of different standards but also from the way of expressing the results.

Antibodies represented a major source of variation in our assay comparisons. GH in biologic samples is essentially a mixture of more than 200 different molecular variants (20). Polyclonal antibodies raised against extractive GH will therefore bind to a multitude of molecular variants regardless of their biologic activity. At the other end of the spectrum are monoclonal antibodies directed against two sites on the $22 \mathrm{kDa} G H$ necessary for receptor dimerization, and GHBP itself to detect predominantly biologically active $\mathrm{GH}$ variants (21). One of the reference assays (IFA) using the latter antibodies in fact yielded the lowest GH values, representing $60.6 \%$ of the concentrations measured with the local assays, $76.5 \%$ of the concentrations of the 
DELFIA assay, and $88.9 \%$ of the Tuebingen assay concentrations, with the Tuebingen assay using the same recombinant standard (1. IRP 88/624). This is in accordance with previously published slopes of IFA regression lines (IFA vs the HybriTech assay 65\%) (22). Further, it has been reported that in some patients $\mathrm{GH}$ peaks appear later after stimulation when measured with an IFA. In a study like ours, in which only the peak serum samples identified by local assays were sent for interlaboratory comparison, this could introduce a bias toward lower GH concentrations measured by IFA (23).

At first sight, some of our data seem to support the notion that assay results could be made comparable by the use of simple conversion factors. However, significant non-linearity existed in all comparisons except the Tuebingen-DELFIA pair, precluding the use of a linear conversion factor. Taking into account the known sources of GH variability, it is not surprising that putting together a group of local assays and comparing it with single reference assays yields higher variability than comparison of two single assays. This, however, reflects the situation in the health care systems of many countries, where the decision to treat a GH-deficient child is based on data from numerous different assays. In the USA, 25 commercially available GH assays are currently listed with the Food and Drug Administration (FDA report 58 FR 39680; CLIA database 12/02; http://www.accessdata.fda.gov/scripts/ cdrh/cfdocs/cfCLIA/search.cfm).

It has been repeatedly stressed that any GH assay and test method must be used exclusively with the cutoff $\mathrm{GH}$ value validated for that specific situation $(1,23)$. In daily practise, arbitrary cutoff GH values are frequently used. Assay variability combined with the use of arbitrary cutoff values for the diagnosis of GH deficiency leads to significant differences with regard to $\mathrm{GH}$ treatment decisions. In one single-center assay comparison study using fixed chosen cutoff values, correlation between individual assay results was high. Nevertheless, agreement between treatment decisions obtained with these assays was low (24). Even in our patients, where cutoff values suggested by the assay manufacturers were used, the diagnostic assignment of patients varied considerably between assays. This finding is in contrast to earlier reports, in which the use of specific cutoff values prevented major non-agreement in diagnostic assignment among some assays (25).

It is mandatory that all patients with $\mathrm{GH}$ deficiency have the same chance of being diagnosed and treated with GH independent of the methods used. Unnecessary treatment must be avoided, because treatment risks, albeit small, do exist $(26-28)$, and the costs of treatment are high.

We suggest that central repeat measurement of peak GH sera in a reference center are a good way of improving comparability of $\mathrm{GH}$ test data within a health system. Repeat measurement could be done by one or two reference assays, perhaps by a combination of a polyclonal assay and an IFA. Since it is not ethically and financially feasable to validate cutoff values for each of the great number of GH assay-functional test combinations currently in use, limitation to small number of reference assays would enable us to set up cutoff values based on sufficient numbers of patients and healthy children with different height velocities.

In conclusion, our data discourage the use of linear conversion systems to make GH results obtained with different assays comparable and to bring diagnostic decisions based on these assays to agreement. To decrease variability related to assays and cutoff values in diagnosing GH deficiency, we recommend nationwide reassessment of $\mathrm{GH}$ peak serum samples of all pediatric patients in central laboratories using reference assays. Decisions to treat GH deficiency should incorporate these results.

\section{Acknowledgements}

The participating investigators of the German KIGS/ IGLU Study Group are as follows: W Andler (Datteln), R Arndt (Neubrandenburg), M Bettendorf (Heidelberg), H J Böhles (Frankfurt/Main), H G Dörr (Erlangen), S Eisberg (Minden), B P Hauffa (Essen), O Hiort (Lübeck), E Korsch (Köln), M Mix (Rostock), K Mohnike (Magdeburg), M Morlot (Hannover), R Mühlenberg (Krefeld), C-J Partsch (Kiel), M B Ranke (Tuebingen), E Schönau (Köln), H-P Schwarz (München), G SimicSchleicher (Bremen), K-P Ullrich (Gotha), $\mathrm{T}$ van Meegen-Freund (Aachen), and Ch Vogel/A Klinghammer (Chemnitz). This work was supported by a grant from Pharmacia Corporation, Erlangen, Germany to B P H and M B R. The authors thank Mrs K Weber for her expert technical assistance and R D Oader, Dept. of Child and Adolescent Psychiatry, University of Essen, for helpful review of the manuscript.

\section{References}

1 Sizonenko PC, Clayton PE, Cohen P, Hintz RL, Tanaka T \& Laron Z. Diagnosis and management of growth hormone deficiency in childhood and adolescence. Part 1: diagnosis of growth hormone deficiency. Growth Hormone and IGF Research 2001 11 137-165.

2 Tassoni P, Cacciari E, Cau M, Colli C, Tosi M, Zucchini S et al. Variability of growth hormone response to pharmacological and sleep tests performed twice in short children. Journal of Clinical Endocrinology and Metabolism 199071 230-234.

3 Loche S, Bizzarri C, Maghnie M, Faedda A, Tzialla C, Autelli M et al. Results of early re-evaluation of growth hormone secretion in short children with apparent growth hormone deficiency. Journal of Pediatrics $2002140445-449$.

4 Dieguez C \& Casanueva FF. Influence of metabolic substrates and obesity on growth hormone secretion. Trends in Endocrinology and Metabolism $1995655-59$.

5 Veldhuis JD, Anderson SM, Shah N, Bray M, Vick T, Gentili A et al. Neurophysiological regulation and target-tissue impact of the pulsatile mode of growth hormone secretion in the human. Growth Hormone and IGF Research 200111 (Suppl A) S25-S37.

6 Veldhuis JD \& Iranmanesh A. Physiological regulation of the human growth hormone $(\mathrm{GH})$-insulin-like growth factor type 1 
(IGF-I) axis: predominant impact of age, obesity, gonadal function, and sleep. Sleep 199619 S221-S224.

7 Rochiccioli P, Enjaume C, Tauber MT \& Pienkowski C. Statistical study of 5473 results of nine pharmacological stimulation tests: a proposed weighting index. Acta Paediatrica 199382 245-248.

8 Granada ML, Sanmarti A, Lucas A, Salinas I, Carrascosa A, Foz M et al. Assay-dependent results of immunoassayable spontaneous 24-hour growth hormone secretion in short children. Acta Paediatrica Scandinavica 1990370 (Suppl) 63-70.

9 Bland JM \& Altman DG. Comparing methods of measurement: why plotting difference against standard method is misleading. Lancet 1995346 1085-1087.

10 Passing $\mathrm{H} \&$ Bablok W. A new biometrical procedure for testing the equality of measurements from two different analytical methods. Journal of Clinical Chemistry and Clinical Biochemistry $198321709-720$.

11 Schoonjans F, Zalata A, Depuydt CE \& Comhaire FH. MedCalc: a new computer program for medical statistics. Computer Methods and Programs in Biomedicine $1995 \mathbf{4 8} 257-262$.

12 Lin LI. A concordance correlation coefficient to evaluate reproducibility. Biometrics $198945255-268$.

13 Sachs L. Angewandte Statistik. Berlin, Heidelberg and New York: Springer-Verlag, 1992.

14 SAS System. Release 8.2 Edition. Carey, NC: SAS Institute, 2002.

15 Israel E, Attie KM, Bengtsson BA, Blethen SL, Blum W, Cameron F et al. Consensus guidelines for the diagnosis and treatment of growth hormone $(\mathrm{GH})$ deficiency in childhood and adolescence: summary statement of the GH Research Society. Journal of Clinical Endocrinology and Metabolism 200085 3990-3993.

16 Juul A, Bernasconi S, Clayton PE, Kiess W \& DeMuinck-Keizer SS. European audit of current practice in diagnosis and treatment of childhood growth hormone deficiency. Hormone Research 2002 $58233-241$.

17 Bidlingmaier F, Geilenkeuser WJ, Kruse R \& Rohle G. Our experience with quality control in current growth hormone assays. Hormone Research 199136 (Suppl 1) 1-4.

18 Seth J, Ellis A \& Al-Sadie R. Serum growth hormone measurements in clinical practice: an audit of performance from the UK National External Quality Assessment Scheme. Hormone Research $19995113-19$.
19 Bristow AF. International standards for growth hormone. Hormone Research 199951 7-12.

20 Baumann G. Growth hormone heterogeneity: genes, isohormones, variants, and binding proteins. Endocrine Reviews 1991 $12424-449$.

21 Strasburger CJ. Methods in determining growth hormone concentrations: an immunofunctional assay. Pediatrics $1999 \mathbf{1 0 4}$ $1024-1028$.

22 Mauras N, Walton P, Nicar M, Welch S \& Rogol AD. Growth hormone stimulation testing in both short and normal statured children: use of an immunofunctional assay. Pediatric Research 200048 614-618.

23 Wood P. Growth hormone: its measurement and the need for assay harmonization. Annals of Clinical Biochemistry 200138 471-482.

24 Rakover Y, Lavi I, Masalah R, Issam T, Weiner E \& Ben Shlomo I. Comparison between four immunoassays for growth hormone (GH) measurement as guides to clinical decisions following $\mathrm{GH}$ provocative tests. Journal of Pediatric Endocrinology and Metabolism $200013637-643$.

25 Andersson A-M, Orskov H, Ranke MB, Shalet S \& Skakkebæk NE. Interpretation of growth hormone provocative tests: comparison of cut-off values in four European laboratories. European Journal of Endocrinology 1995132 340-343.

26 Cutfield WS, Wilton P, Bennmarker H, Albertsson-Wikland K, Chatelain P, Ranke MB et al. Incidence of diabetes mellitus and impaired glucose tolerance in children and adolescents receiving growth-hormone treatment. Lancet 2000355 610-613.

27 Christiansen JS, Bengtsson BA, Thorner MO, Hintz R, Sonksen PH, Cohen $\mathrm{P}$ et al. Critical evaluation of the safety of recombinant human growth hormone administration: statement from the growth hormone research society. Journal of Clinical Endocrinology and Metabolism 200186 1868-1870.

28 Swerdlow AJ, Higgins CD, Adlard P \& Preece MA. Risk of cancer in patients treated with human pituitary growth hormone in the UK, 1959-1985: a cohort study. Lancet $2002360273-277$.

Received 19 May 2003

Accepted 3 December 2003 